\title{
CENTRAL OBESITY AS A RISK FACTOR OF HYPERTENSION IN ELDERLY AT BANJARARUM VILLAGE SINGOSARI MALANG
}

\author{
Rizqi Suryani Putri ${ }^{\mathrm{a}(\mathrm{CA})}$, Lilik Djuari ${ }^{\mathrm{b}}$, \\ Subur Prajitno
}

\author{
a rizqisuryaniputri@gmail.com \\ ${ }^{a}$ Faculty of Medicine, Universitas Airlangga, Surabaya, Indonesia \\ b Department of Public Health, Faculty of Medicine, Universitas Airlangga, Surabaya, Indonesia
}

\begin{abstract}
Background: Hypertension is one of the common health problems in developing countries. The prevalence of hypertension increases with age. There are several factors that can trigger the incidence of hypertension, and one of them is obesity. Excessive fat in the body will disrupt circulation and give pressure to blood vessels. Aim: This study aims to analyse central obesity as a risk factor for hypertension at Banjararum Village, Singosari, Malang, Indonesia. Method: A case control study was carried out to 44 respondents who were elderly that fulfil the inclusion criteria at Banjararum Village, Singosari, Malang, East Java, Indonesia using purposive sampling. This study used primary data by doing physical examination to the respondents and a questionnaire to identify respondents who already diagnosed with hypertension. Data were analysed with the Chi-square test. Results: This study showed a significant result that central obesity is a risk factor of hypertension in elderly $(\mathrm{p}=0.027, \mathrm{p}<$ $0,05)$ with majority female respondents aged above 59 years old. Conclusion: Central obesity is a risk factor of hypertension in elderly. Elderly with central obesity had 5 times higher prevalence of hypertension than elderly without central obesity.
\end{abstract}

Keywords: Central obesity ; Hypertension ; Elderly 


\section{INTRODUCTION}

Hypertension is one of the common health problems in developing countries. One billion people worldwide suffer from hypertension and two thirds of them are from low- and middle-income developing countries. Hypertension is a non-infectious disease caused by impaired heart and blood vessel function. Hypertension is a condition in which systolic arterial blood pressure raised more than or equal to 140 $\mathrm{mmHg}$, diastolic pressure raised more than or equal to $90 \mathrm{mmHg}$, or both. Hypertension is a serious medical condition and can increase the risk of heart, brain, kidney and other diseases. It is a major cause of premature death worldwide (WHO, 2011).

The prevalence of hypertension increases with age. From 14.7\% in the 25-34 years age group, increase to $24.8 \%$ in the 35-44-year age group and become $57.6 \%$ in the group of 65 -year age above. The prevalence in women (28.8\%) was higher than in men (22.8\%) (Banshal, 2012). According to Indonesia Basic Health Research (IBHR) in 2013, hypertension is one of the most common diseases in the elderly. They also stated that $57.6 \%$ of the population aged over 60 years suffered from hypertension.

There are several factors that can trigger the incidence of hypertension, one of them is obesity. Excessive fat in the body will disrupt circulation and give pressure to blood vessels (Ponto, Kandou, \& Mayulu, 2016). Obesity increases blood pressure by increasing renal tubular sodium reabsorption, impairing pressure natriuresis, and causing volume expansion through activation of the sympathetic nervous system and the renin-angiotensin-aldosterone system and by physical compression of the kidneys, especially when there is increased visceral adiposity (Hall et al., 2014).

A study revealed that waist circumference increases the risk of hypertension (Yap et al, 2006). Accumulation of fat that occurs in the intra-abdominal area is called central obesity. Central obesity cause the risk of experiencing health problems, especially those associated with cardiovascular disease is higher. Central obesity mechanism for hypertension could lead to unbalanced glucose tolerance. High level of insulin would circulate and reduce the sensitivity of insulin metabolic activity. These conditions could lead to hyperinsulinemia that affects the rise in blood pressure (Kotsis et al, 2010).

According to the health profile of Singosari Public Health Center, Banjararum Village had the highest cases of hypertension. Around $60 \%$ of the citizen above 59 years old were diagnosed with hypertension. Therefore, this study aims to analyze central obesity as a risk factor for hypertension at Banjararum Village, Singosari, Malang to give early intervention to reduce complications and patient mortality.

\section{METHODS}

A case control study was carried out on July 2016. Fourty four elderly at Banjararum Village, Singosari, Malang City were included using purposive sampling for analysis. The inclusion criteria were elderly aged more than 59 years old, lived at Banjararum Village Singosari Malang, and had given 
consent to participate in the study. The exclusion criteria were patients who has abdominal tumor or urogenital or ascites (excessive fluid in the abdominal cavity), patients who could not communicate well and patients who refused to be involved. This study used primary data by doing physical examination to the subjects. Sphygmomanometer were used to measure blood pressure (considered hypertension if systole $\geq 140 \mathrm{mmHg}$ or diastole $\geq 90 \mathrm{mmHg}$ or both) and tape measure were used to measure waist circumference (considered central obesity if waist circumference was $>80 \mathrm{~cm}$ for female and $>90 \mathrm{~cm}$ for male). A questionnaire was also given to the subject to identify subjects who had controlled hypertension status or take antihypertensive medication so their blood pressure might measure as normal during the physical examination.

The collected data were analysed for data cleaning, coding, and tabulation. Data analysis was performed using IBM SPSS Statistics for Windows version 17. The research uses comparative study to identify central obesity as a predictor of hypertension. So, this study consisted of two groups of samples which were group with hypertension (disease +) and group without hypertension (disease -). Both groups were independent. Univariate data is presented in a frequency and distribution, while the bivariate analysis used in this study used the Chi square test. Variables with a p-value $<0.05$ from the bivariate analysis were considered significant.

\section{RESULTS}

\subsection{Characteristics of the Elderly at Banjararum Village Singosari Malang}

Among 44 respondents, most of the respondents were in the group of age 60-64 years (47.7\%, $\mathrm{n}=21$ ). The sex ratio of women is $91 \%$ while men is $9 \%$. Forty one $(93.2 \%)$ respondents were unemployed and $34 \%$ of the respondents graduated from junior high school. Thirty three (75\%) of respondents had central obesity. The respondents were divided into 2 groups, the case group consist of 22 respondents with hypertension and the control group consist of 22 respondents without hypertension. The detailed characteristics of the respondents can be seen in Table 3.1.

Table 3.1. Characteristics of the Elderly at Banjararum Village Singosari Malang

\begin{tabular}{ccc}
\hline Characteristics & $\mathbf{n}$ & $\%$ \\
\hline Age & 21 & $47.7 \%$ \\
$60-64$ & 7 & $15.9 \%$ \\
$65-69$ & 16 & $36.4 \%$ \\
$70-74$ & 44 & $100 \%$ \\
Total & & $9 \%$ \\
Gender & 4 & $91 \%$ \\
Male & 40 & $100 \%$ \\
Female & 44 & $93.2 \%$ \\
Total & & $6.8 \%$ \\
Job & 41 & $100 \%$ \\
Enemployed & 3 &
\end{tabular}




\begin{tabular}{ccc}
\hline Education & 5 & $11 \%$ \\
No formal school & 7 & $16 \%$ \\
Elementary School & 15 & $34 \%$ \\
Junior High School & 14 & $32 \%$ \\
Senior High School & 3 & $7 \%$ \\
College & 44 & $100 \%$ \\
Total & 11 & \\
Central Obesity & 33 & $25 \%$ \\
Non-Central Obesity & 44 & $75 \%$ \\
Central Obesity & $100 \%$ \\
Total & 22 & \\
\hline Hypertension & 22 & $50 \%$ \\
Non-Hypertension & 44 & $50 \%$ \\
Hypertension & & $100 \%$ \\
Total & &
\end{tabular}

\subsection{Characteristics of the Elderly at Banjararum Village Singosari Malang based on central obesity} status

Our findings indicated that out of 22 respondents who had central obesity, most of the respondents were in the group of $60-64$ years old, female, unemployed and graduated from junior high school.

Table 3.2. characteristic of the Elderly based on central obesity status

\begin{tabular}{|c|c|c|c|}
\hline Characteristics & $\begin{array}{c}\text { Central obesity } \\
\text { n(\%) }\end{array}$ & $\begin{array}{c}\text { Non - central obesity } \\
\text { n (\%) }\end{array}$ & $\begin{array}{c}\text { Total }(\%) \\
n=44\end{array}$ \\
\hline \multicolumn{4}{|l|}{ Age } \\
\hline $60-64$ & $15(71.4 \%)$ & $6(28.6 \%)$ & $21(47.7 \%)$ \\
\hline $65-69$ & $5(71.4 \%)$ & $2(28.6 \%)$ & $7(15.9 \%)$ \\
\hline $70-74$ & $13(81.3 \%)$ & $3(18.7 \%)$ & $16(36.4 \%)$ \\
\hline \multicolumn{4}{|l|}{ Gender } \\
\hline Male & $2(50 \%)$ & $2(50 \%)$ & $4(9 \%)$ \\
\hline Female & $31(77.5 \%)$ & $9(22.5 \%)$ & $40(91 \%)$ \\
\hline \multicolumn{4}{|l|}{ Job } \\
\hline Unemployed & $32(78 \%)$ & $9(22 \%)$ & $41(93.2 \%)$ \\
\hline employed & $1(33.3 \%)$ & $2(66.7 \%)$ & $3(6.8 \%)$ \\
\hline \multicolumn{4}{|l|}{ Education } \\
\hline No formal school & $5(100 \%)$ & $0(0 \%)$ & $5(11 \%)$ \\
\hline Elementary School & $6(85.7 \%)$ & $1(14.3 \%)$ & $7(16 \%)$ \\
\hline Junior High School & $10(66.7 \%)$ & $5(33.3 \%)$ & $15(34 \%)$ \\
\hline Senior High School & $9(64.3 \%)$ & $5(35.7 \%)$ & $14(32 \%)$ \\
\hline College & $3(100 \%)$ & $0(0 \%)$ & $3(7 \%)$ \\
\hline
\end{tabular}




\subsection{Correlation Between Central Obesity and Hypertension in Elderly at Banjararum Village Singosari Malang}

The chi square test showed a significant result that central obesity is a risk factor of hypertension in elderly $(\mathrm{p}=0.027, \mathrm{p}<0,05)$. This study revealed that twenty respondents $(45.5 \%)$ with central obesity had been diagnosed with hypertension while nine respondents $(20.5 \%)$ without central obesity had normal blood pressure and never had been diagnosed with hypertension. The cross-tabulation between central obesity and hypertension was presented in Table 3.3.

Table 3.3. Bivariate Analysis between hypertension and central obesity in Elderly at Banjararum Village Singosari Malang

\begin{tabular}{|c|c|c|c|c|c|}
\hline & & \multicolumn{2}{|c|}{ Hypertension status } & \multirow[t]{2}{*}{ Total } & \multirow{2}{*}{$\begin{array}{l}\text { p-value } \\
\text { and OR }\end{array}$} \\
\hline & & No & Yes & & \\
\hline \multirow{4}{*}{$\begin{array}{c}\text { Central } \\
\text { Obesity status }\end{array}$} & & & & \multicolumn{2}{|l|}{$\mathrm{n}=44(\%)$} \\
\hline & No & $9(20.5 \%)$ & $2(4.5 \%)$ & $11(25 \%)$ & $\mathrm{p}=0.027$ \\
\hline & & & & & $\mathrm{OR}=5$ \\
\hline & Yes & $13(29.5 \%)$ & $20(45.5 \%)$ & $33(75 \%)$ & \\
\hline
\end{tabular}

\section{DISCUSSION}

Forty four respondents were analysed based on several characteristics. As presented in table 3.1. in the previous chapter, the elderly at Banjararum Village, Singosari, Malang, Indonesia who fulfilled the inclusion criteria were mostly in the age of 60 to 64 years old, female, unemployed and had central obesity. While the prevalence of hypertension could not be analyzed because in this study the characteristics of the control group (non-hypertension) were made as similar as the case group (hypertension) such as age and gender so the risk factor can be identified.

The prevalence of central obesity increases with age. It showed that $71.4 \%$ of respondents had central obesity in the age group of 60-64 years old. It significantly increase in the age group of 70-74 years old, $81.25 \%$ respondents had central obesity. According to World Health Organization, when a person is getting older, his or her incidence of having central obesity is expected to increases. Increased abdominal circumference is higher in women. This is in line with the result of this study that the majority of respondent who had central obesity were female $(n=31,77.5 \%)$. The high rates of central obesity among unemployed respondents happened because the physical activities of unemployed people are less than those who work. Physical activities can facilitate blood flow while the lack of physical activities can increase the risk of obesity and hypertension (Diaz, 2013).

Out of 44 respondents, our analysis revealed a significant result that central obesity is a risk factor of hypertension in elderly ( $\mathrm{p}=0.027, \mathrm{p}<0,05)$. This is in accordance with the results of Aguirre et al study in 2015, reported that there was a relationship between abdominal circumference and systolic $(\mathrm{p}=0.007)$ and diastolic $(0.008)$ blood pressure. Central obesity mechanism for hypertension could lead 
to unbalanced glucose tolerance. High level of insulin would circulate and reduce the sensitivity of insulin metabolic activity. These conditions could lead to hyperinsulinemia that affects the rise in blood pressure (Kotsis et al, 2010).

Another study reported that obesity which was followed by increasing of fat metabolism leads to higher production of reactive oxygen species (ROS) in the circulation and in adipose cells. Reactive Oxygen Species (ROS) can stimulate inflammation, activate matrix metalloproteinases, induce apoptosis, cause platelet aggregation and stimulate smooth muscle. ROS also play a role in modulating growth tone and vascular remodelling. The increase of ROS in adipose cells will disrupt the balance of oxidation-reduction reactions, resulting in a decrease in circulating antioxidant enzymes. This situation is called oxidative stress. Oxidative stress is believed to have an important role in the pathophysiology of hypertension, metabolic syndrome, and atherosclerosis (Stern et al, 2004).

The odd ratio is 5 . This result indicates that elderly with central obesity had 5 times higher prevalence of hypertension than elderly without central obesity. Based on Dian Meutia's study in 2013, the results of the bivariate analysis showed that people with central obesity (women's waist circumference $>80 \mathrm{~cm}$ ) had a $1.5 \mathrm{x}$ risk of hypertension. The odd ratio had a different results with this study, it might be caused by the different segmentation of the respondents gender, which all the subjects in that study were female, while in this study the subjects consist of male and female.

\section{CONCLUSION}

The majority of respondents who had central obesity at Banjararum Village, Singosari, Malang were in the age of 60 to 64 years old, female, and unemployed. Based on the chi square test, it was showed a significant result that central obesity is a risk factor of hypertension in elderly $(\mathrm{p}=0.027, \mathrm{p}<$ $0,05)$. Elderly with central obesity had 5 times higher prevalence of hypertension than elderly without central obesity.

\section{REFFERENCES}

- Aguirre, T., Koehler, A. and Tovar, A., 2015. Relationships among hypertension, waist circumference, and body composition in a rural mexican-american population. J Family Med Community Health, 2(7), p.1057.

- Badan Penelitian dan Pengembangan Kesehatan. Riset kesehatan dasar (RISKESDAS) 2013. Lap Nas. 2013;2013:1-384.

- Banshal SK, et al. 2012. The Prevalence of Hypertension and Hypertension Risk Factors in a Rural Indian Community: A Perspective door-to-door study. J Cardiovasc Dis Res 117-23 doi: 10.4103/09753583

- Diaz, K.M. and Shimbo, D., 2013. Physical activity and the prevention of hypertension. Current hypertension reports, 15(6), pp.659-668.

- Eugene Braunwald .2012. Harrison's principles of internalmedicine $18^{\text {th }}$ ed. atau editors, p. cm. The McGraw-Hill Companies, Inc., for manufacture and export. 
- Gotera, W., Aryana, S., Suastika, K., Santoso, A. and Kuswardhani, T., 2006. Hubungan antara obesitas sentral dengan adiponektin pada pasien geriatri dengan penyakit jantung koroner. Jurnal penyakit dalam, 7(2), pp.102-7.

- Hall, J., Juncos, L., Wang, Z., Hall, M., do Carmo, J., \& da Silva, A. 2014. Obesity, hypertension, and chronic kidney disease. International Journal of Nephrology and Renovascular Disease, 7, 75. https://doi.org/10.2147/IJNRD.S39739

- Kemenkes RI. 2014. Pusat Data dan Informasi Kementrian Kesehatan RI Hipertensi. Jakarta. Kemenkes RI.

- Klein, S., Allison, D.B., Heymsfield, S.B., Kelley, D.E., Leibel, R.L., Nonas, C. and Kahn, R., 2007. Waist circumference and cardiometabolic risk: a consensus statement from shaping America's health: Association for Weight Management and Obesity Prevention; NAASO, the Obesity Society; the American Society for Nutrition; and the American Diabetes Association. The American journal of clinical nutrition, 85(5), pp.1197-1202.

- Kotsis, V., Stabouli, S., Papakatsika, S., Rizos, Z. and Parati, G., 2010. Mechanisms of obesity-induced hypertension. Hypertension research, 33(5), pp.386-393.

- $\quad$ Lofgren, I., Herron, K., Zern, T., West, K., Patalay, M., Shachter, N.S., Koo, S.I. and Fernandez, M.L., 2004. Waist circumference is a better predictor than body mass index of coronary heart disease risk in overweight premenopausal women. The Journal of nutrition, 134(5), pp.1071-1076.

- Macera, C.A., Ham, S.A., Yore, M.M., Jones, D.A., Kimsey, C.D., Kohl III, H.W. and Ainsworth III, B.E., 2005. PEER REVIEWED: Prevalence of Physical Activity in the United States: Behavioral Risk Factor Surveillance System, 2001. Preventing chronic disease, 2(2).

- Meutia Sari, Dian. 2013. Hubungan obesitas sentral terhadap kejadian hipertensi stage 1 di pos pembinaan terpadu penyakit tidak menular kota Padang Panjang tahun 201. Depok : FKMUI.

- Pischon, T., Boeing, H., Hoffmann, K., Bergmann, M., Schulze, M.B., Overvad, K., Van der Schouw, Y.T., Spencer, E., Moons, K.G.M., Tjønneland, A. and Halkjaer, J., 2008. General and abdominal adiposity and risk of death in Europe. New England Journal of Medicine, 359(20), pp.2105-2120.

- Ponto, L., Kandou, G.D. and Mayulu, N., 2016. Hubungan antara obesitas, konsumsi natrium, dan stres dengan kejadian hipertensi pada orang dewasa di Puskesmas Tompaso Kabupaten Minahasa. Fakultas Kesehatan Masyarakat Universitas Sam Ratulangi, pp.115-129.

- Ritchie, S.A. and Connell, J.M.C., 2007. The link between abdominal obesity, metabolic syndrome and cardiovascular disease. Nutrition, Metabolism and cardiovascular diseases, 17(4), pp.319-326.

- Shen, W., Punyanitya, M., Chen, J., Gallagher, D., Albu, J., Pi-Sunyer, X., Lewis, C.E., Grunfeld, C., Heshka, S. and Heymsfield, S.B., 2006. Waist circumference correlates with metabolic syndrome indicators better than percentage fat. Obesity, 14(4), pp.727-736.

- Stern, M.P., Williams, K., González-Villalpando, C., Hunt, K.J. and Haffner, S.M., 2004. Does the metabolic syndrome improve identification of individuals at risk of type 2 diabetes and/or cardiovascular disease?. Diabetes care, 27(11), pp.2676-2681.

- Stevens, J., Katz, E.G. and Huxley, R.R., 2010. Associations between gender, age and waist circumference. European journal of clinical nutrition, 64(1), pp.6-15.

- Thoonen, R., Sips, P.Y., Bloch, K.D. and Buys, E.S., 2013. Pathophysiology of hypertension in the absence of nitric oxide/cyclic GMP signaling. Current hypertension reports, 15(1), pp.47-58.

- Wang, Z.V. and Scherer, P.E., 2008. Adiponectin, cardiovascular function, and hypertension. Hypertension, 51(1), pp.8-14. 
- Wannamethee, S.G., Shaper, A.G., Morris, R.W. and Whincup, P.H., 2005. Measures of adiposity in the identification of metabolic abnormalities in elderly men. The American journal of clinical nutrition, 81(6), pp.1313-1321.

- World Health Organization (WHO) . 2011. Global Health Observatory (GHO) data Raised Blood Pressure.

- Yap, S., Yang, Z., Wang, J., Bacon, S.L. and Campbell, T.S., 2006. Waist circumference, not body mass index, is associated with blood pressure in a sample of young Chinese adults. Journal of human hypertension, 20(11), pp.904-906. 